Please cite this paper as: Navarro, A.; Puig, R.; Kiliç, E.; Penavayre, S; Fullana-i-Palmer, P. Ecoinnovation and benchmarking of Carbon Footprint data for vineyards and wineries in Spain and France. Journal of Cleaner Production (2016). http://dx.doi.org/10.1016/j.jclepro.2016.11.124

\title{
Eco-innovation and benchmarking of Carbon Footprint data for vineyards and wineries in Spain and France
}

\author{
Alejandra Navarro ${ }^{1,2}$, Rita Puig ${ }^{l}$, Eylem Kulıç ${ }^{3}$, Sophie Penavayre ${ }^{4}$, Pere Fullana-i-Palmer ${ }^{5,2}$ \\ ${ }^{1}$ GIR, Escola d'Enginyeria d'Igualada (EEI), Universitat Politècnica de Catalunya (UPC, Barcelona \\ tech), Pla de la Massa, 8, 08700 Igualada, Spain. \\ ${ }^{2}$ Cyclus Vitae Solutions, S.L., Avinguda Caresmar 33, 1; 08700 Igualada, Spain \\ ${ }^{3}$ Usak University, 1 Eylul Campus, 64200 Uşak, Turkey. \\ ${ }^{4}$ IFV, Institut Français de la Vigne et du Vin, Domaine de l'Espiguette 30240 Le Grau du Roi, France \\ ${ }^{5}$ UNESCO Chair in Life Cycle and Climate Change (ESCI-upf), Pg. Pujades 1, 08003 Barcelona, \\ Spain.
}

*Corresponding author: Rita Puig, Tel.:+34938035300; Fax:+34938031589. E-mail address: rita.puig@eei.upc.edu

\begin{abstract}
Environmental sustainability in the wine sector has become a priority, as a result of both the growing interest in environmental issues and the consumer's demand for more information regarding the environmental impact of the products they purchase. In this context, the use of carbon footprint as an indicator to assess and report the environmental burdens associated with wine production has gained a role of primary interest. The present study has the aim of improving the wine sector's sustainability by providing inventory data on wine production systems from a total of 18 wineries located in major wine-producing regions in Spain and the South of France. The main novelty of this paper is: the corporate carbon footprint approach, the greater number of wineries studied, the diversity of location of those wineries, the detail of data presented and the identification of the best reference flow for vineyards. Data was statistically analysed. Vineyard consumptions are usually related to the area of cultivation. However, although 1 hectare of vineyard or $1 \mathrm{~kg}$ of harvested grape could both be considered good reference flows for vineyard processes, this study shows a greater standard deviation of average data calculated per ha rather than per kg. Impact results show a major contribution of the winery phase to the corporate carbon footprint (73\%), mainly due to glass production for bottling (45.6\% contribution) and electricity consumption (9.2\%). In the vineyard phase, contribution comes mainly from diesel production and combustion due to field works (11.3\%) and the use of phytosanitary products $(6.0 \%)$. The results revealed that with the establishment of best practices and with optimized resource consumption, the corporate carbon footprint values can be reduced by almost $25 \%$. The comparative results presented can be used as a reference that will enable wineries to compare their impacts to the average, to identify in which aspects they are within the average and which aspects they are outside the average and whether these aspects are significant to their carbon footprint. This may encourage wineries to adopt measures for Eco-innovation through carbon emission reduction.
\end{abstract}


Key words: corporate carbon footprint, Eco-innovation, vineyard, winery, wine industry's environmental performance, inventory data

\section{Introduction}

Wine production constitutes one of the most ancient economic sectors and is still at present a very important agri-food activity in Europe. Among the main worldwide producers, Southern European countries, Spain and France, currently have the highest surface area of territory dedicated to wine production (Salvat \& Boqué, 2009). Grape growing accounts for a large majority of agricultural activities in regions where wine production is concentrated and, similarly to other agricultural activities, it has a significant impact on the environment due to the use of fertilizers, pesticides, water and energy, soil erosion and land use, and to the production of substantial amounts of organic waste (BREF of food, drink and milk industry, 2006).

In the past decade, pressure from environmental authorities and an increasing interest from consumers and foreign importers in environmental issues leading to a higher demand for information regarding the environmental impact of the products they purchase, have led to new appellations and quality standards resulting in a steady decline of wine production in Europe (OIV, 2012). In order to keep up with the current demand trends and to improve market quota, competitiveness and consumer satisfaction, a growing number of stakeholders in the wine sector has started to analyze and disseminate environmentally relevant results (Szolnoki, 2013). Consequently, environmental sustainability has become a priority for those involved in the wine supply chain (Forbes et al., 2009).

In this context, the application of life cycle assessment (LCA) as a standardized environmental management tool (ISO 14040, 2006; ISO 14044, 2006) has gained a role of primary interest within the extensive literature, regarding assessment of the different environmental burdens associated with wine production for moving toward sustainable grape growing and wine production practices (Rugani et al., 2013). Wine LCA studies vary on the type of wine (Fusi et al., 2014, Pattara et al., 2012; Amienyo et al., 2014) the country where wine is produced, such as Spain (Vázquez-Rowe et al., 2012a; 2012b), France (Bellon-Maurel, V., et al., 2015), Italy (Benedetto, 2013; 2014; Iannone et al., 2016; Marras, S., et al., 2015), Portugal (Neto et al., 2013), Australia (Thomas, 2011), Canada (Point et al., 2012; Steenwerth, K.L., et al., 2015) and the life cycle stages included in the study, cradle to grave (Gazulla et al., 2010) or cradle to gate (Pattara et al., 2012). Although LCA has proven to be useful to quantify the environmental burdens associated within life cycle stages of wine, it has disadvantages due to its wide scope in terms of system boundaries or multiple impact categories.

Certainly, in Europe, there is a huge ongoing effort to improve and promote the use of LCA in different sectors, including the wine sector, through the $\mathrm{PEF}^{1}$ and $\mathrm{OEF}^{2}$ methodologies of the Single Market of Green Products Initiative ${ }^{3}$. However, there is an even higher worldwide trend of simplification (Baitz et al., 2013; Bala et al., 2010) focussing on a single indicator, carbon footprint, relevant to global warming, which is internationally considered as critical environmental concern (Pattara et al., 2012; Weidema et al., 2008). Being a one-indicator methodology doesn't mean that there are no methodological pending issues in carbon footprint calculation; for instance, the accounting of organic carbon is of great importance (Arzoumanidis et al., 2014). Carbon footprint may be assessed at product level, following the LCA methodology for only this one impact category and following standards such as: PAS 2050 (2011), ISO 14067 (2013) or GHG Protocol for products (2011). It can also be assessed at corporate level, following standards such as: ISO 14064 (2006) or GHG Protocol for organisations (2004).

\footnotetext{
${ }^{1}$ Product Environmental Footprint

${ }^{2}$ Organisation Environmental Footprint

${ }^{3}$ http://ec.europa.eu/environment/eussd/smgp/
} 
Corporate carbon footprint can be calculated at three scopes (GHG corporate protocols, 2004 and 2011): 1) direct emissions, 2) emissions from electricity production and 3) indirect emissions upstream or downstream on the production chain. There are a number of industrial sectors which have high greenhouse gas (GHG) emissions at their facilities (mainly due to combustion) or because of their intensity in electricity use. Those which are affected by EU Directives and the dominant scopes are scope 1 and 2 (DIRECTIVE 2003/87/EC). The rest of the economic sectors have diffuse emissions and are normally found within the scope 3 . In order to calculate any contribution (emission factor) from a process within scope 3 , such as the emissions produced due to the production of fuel or a certain raw material, or the management of a certain waste, there is a need to use the LCA methodology (GHG corporate protocol, 2011). Therefore, whether a complete LCA is needed or only a product carbon footprint or a scope 3 corporate carbon footprint, there is somehow a need for LCA methodology.

The wine sector has started to follow the trend for simplification. Some carbon footprint studies of wine production systems have been published, either product (Vazquez-Rowe et al., 2013; Cholette and Venkat, 2009; Pattara et al., 2012) or corporate (Marras, S., et al., 2015; Penela, et al., 2009), and carbon calculators have also been developed for the wine sector (IWCC; WFA, 2011; Colman \& Päster, 2009). . The corporate studies refer to one vineyard in Italy (Marras, S., et al., 2015) and a winery in Spain (Penela, et al., 2009).This last study does not present the inventory data.

Most of the wine literature refers to product LCA studies (not really carbon footprint), thus providing a picture of the environmental profile of the wine sector and identifying the main hotspots throughout the wine production chain. Nevertheless, a review of those studies revealed that they have been focussing on either only one type of wine from only one winery (Neto et al., 2013; Fusi et al., 2014; Benedetto, 2013; Vázquez-Rowe et al., 2012b) or a higher number of wineries but within a specific region or production phase: vineyards in Galicia (Vázquez-Rowe et al., 2012a) and wineries in La Rioja (Gazulla et al., 2010). And, where multiple types of wine and different regions were studied, most of the inventory data was gathered from previously published studies, with different years of production and system boundaries (Vázquez-Rowe et al., 2013).

The value of the present paper, compared with the previous literature, is in the corporate carbon footprint approach used, the statistical treatment of inventory data from a greater number of wineries than previously published, the location of these wineries (different regions in Spain and France) and different types of wine (red and white).

Hence, the main objective of the article is to provide inventory data on wine production systems from 18 wineries ( 3 cooperatives) located in 2 countries, 7 regions, 14 denominations of origin (see Table 2) in order:

(i) to be used as background data for corporate carbon footprint of wineries or product carbon footprint of wine and derived products;

(ii) to highlight the main hot spots contributing to the carbon footprint of this sector;

(iii) to show opportunities for improvement of sustainability and competitiveness within the wine production system;

(iv) to help wineries benchmark and monitor their environmental performance against the mean values obtained.

An internal critical review of the collected inventory data and a comparative statistical study of chemical and energy consumptions per hectare of vineyards and per $\mathrm{kg}$ of grapes have also been performed.

\section{Materials and methods}

\subsection{Methodology}

Corporate carbon footprint following the ISO 14064 standard methodology was used to analyse the GHG emissions from 18 wineries. This method is a bottom-up process analysis, which begins with 
collecting and analysing a great deal of specific information from all the processes involved in the production of 1 bottle of wine. Thus, quantities of material and energy consumptions/inputs and emissions/outputs per one year was gathered from all involved companies and processes.

The bottom-up process analysis is limited, and truncates life-cycle stages further upstream. This phenomenon is well known as "truncation errors" (see examples for wood and steel by Lenzen and Treloar, 2002 and Lenzen and Dey, 2000, respectively) and can be ascribed to the finite system boundary. Unfortunately such truncation errors are systematic and not stochastic (Lenzen, 2000), thus rendering any comparisons or statements about relative proportions invalid (see Lenzen and Treloar, 2003). One approach to overcome such systematic truncation errors is to combine bottom-up process analysis with top-down input-output analysis into a hybrid Life-Cycle Assessment method (Heijungs and Suh, 2002; Suh, et al., 2004; Suh and Huppes, 2005; Suh and Nakamura, 2007). Such a hybrid assessment combines the best of both worlds - specificity and completeness (Bullard, et al., 1978; Moskowitz and Rowe 1985); the truncation errors of process analysis are avoided, as well as the aggregation errors of input-output analysis (Gibbons, et al., 1982; Kymn ,1990; Murray, 1998; Lenzen, 2011; Steen-Olsen, et al., 2014). Hybrid assessments of agricultural production systems have been undertaken before (ie. Wood, et al., 2006). Nevertheless, this hybrid Life-Cycle Assessment method is not within the scope of the present paper, although it can be used in future works.

Corporate carbon footprint methodology (ISO 14064 and GHG corporate protocols, 2004 and 2011) consists of calculating direct and indirect GHG emissions produced, as a result of the company's activities during one year. Direct emissions refer to emissions taking place in the company itself (ie. emissions from fuel combustion), while indirect emissions take place elsewhere (ie. emissions from the production of electricity purchased by the company). To quantify indirect emissions from purchased electricity (scope 2), goods and fuels, transport and waste management (scope 3), life cycle methodology (ISO 14044) is used. In this study, indirect emissions were calculated from company data and by using emission factors from LCA databases (ie. ecoinvent, Thinkstep and ELCD).

According to the standards, companies are free to include or exclude scope 3 indirect emissions in their corporate carbon footprint. In this study, scope 3 categories 1 (purchased goods and services), 3 (fuel and energy related activities, not included in scopes 1 and 2) and 5 (waste generated) were included in the study, while other categories, like business travel, the commuting of employees and product distribution were out of the scope due to their probably low influence or the difficulties on data gathering from the company.

\subsection{System description}

The inventory data has been collected from various types of wine production processes (2013 campaign), predominately from red wine production (by 80\%), using different kinds of grapes such as Tempranillo, Chardonnay or Grenache among others, in 18 wineries (3 wine cooperatives) with wineyards in 7 production regions and 14 denominations of origin (Table 2 and Figure 1). The winery cooperatives are associations which produce wine, from a great number of affiliated vineyards, and provide other services to their affiliated vineyards (ie. to supply fertilizers and phytosanitary products, to rent machinery or provide other services to them). Vineyards affiliated to cooperatives can have different denominations of origin (DO). Thus, cooperatives produce wine from different DO, but the data on Table 2 corresponds only to the indicated DO.

Specifically, data has been collected from corporative carbon footprint studies within the scope of the $\mathrm{CO} 2$ Vino and VINECO projects, conducted with the aim of improving the wine 
sector's sustainability. A specific number of wineries had to be chosen from the regions determined by each project: in CO2 Vino should be from Galicia (2), Castilla La Mancha (5) and Murcia (1) and in VINECO from Midi Pyrenees (4), Langedoc-Roussillon (2), Catalonia (2) and Balearic Islands (2) (see Figure 1). The process of choosing the participating wineries was as follows: 1) information about the project was sent by email to all wineries in the involved regions; 2) a seminar was held in each region to explain the project and the benefits of participating; 3 ) wineries that were willing-to-participate had to register through a website; 4) all companies registered were contacted to be sure that they understood their duties (data providing and scheduling); 5) unreliable companies were excluded from the selection process; 6) a raffle was held amongst the remaining wineries from the same region. The wineries were not selected to be representative of the involved regions but to be reliable on gathering and providing rigorous data within the schedule.

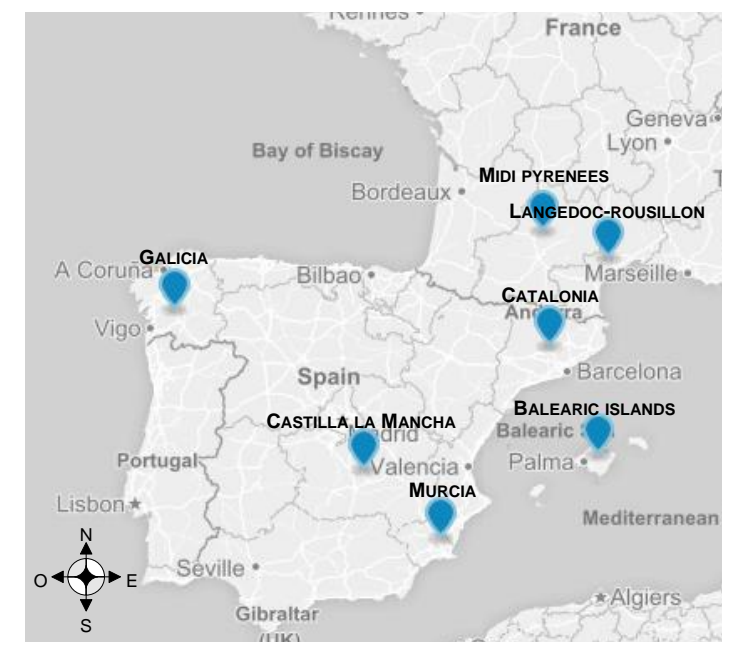

Figure 1. Location of wineries studied in the scope of the study (source: modified from Mapbox, 2015).

The system boundaries of this analysis include all major material and energy flows associated with life cycle stages such as grape growing, wine making and bottling and packaging (Figure 2). The wine production system involves two main subsystems: vineyard (i.e., cultivation and harvesting of the grapes) and winery. Water use, on vineyards and in wineries, was excluded due to lack of data. As it varies a lot from one year to the other, transportation was either not included in the system boundaries, except the transport of harvested grapes to the wine production facilities. Primary data was collected through the use of questionnaires and personal communication with representatives of the wineries. These questionnaires involved main direct inputs and key operational aspects of the vineyard, wine making, bottling and packaging processes of wine production. All questionnaires were examined and compared in order to find values far from the mean and to ensure the quality of data. After checking, very different values were noted, as production practises differ a lot from one company to the other.

In order to obtain the necessary data for the study, a questionnaire was developed (using the experience of the authors in a previous EU financed project (LIFE $08 \mathrm{ENV/E} / 000143$ ). The questionnaire was divided in 3 excel sheets: general aspects, vineyard (asking data about consumptions and emissions for each delivering farm) and winery (asking data about consumptions and wastes during the winemaking process and the bottling) (see Table 1). Visits to the wineries to 
help filling the questionnaire were performed, together with subsequent contacts through e-mail and phone calls to address the pending issues.

Table 1. Type of information asked in the questionnaires.

\begin{tabular}{|c|c|c|}
\hline General Aspects & Vineyard & Winery \\
\hline $\begin{array}{l}\text { Winery name } \\
\text { Year of data } \\
\text { Denomination of origin } \\
\text { Contact person } \\
\text { Process flow diagram } \\
\text { Total production of wine } \\
\quad \text { Own wine (L) } \\
\quad \text { Wine bought (L) }\end{array}$ & $\begin{array}{l}\text { Farm name and location } \\
\text { Cultivated area (ha) } \\
\text { Types of grape and amount } \\
\text { produced (kg) } \\
\text { Diesel consumption in vehicles } \\
\text { (own / rented) (L) } \\
\text { Transport of grape to the winery } \\
(\mathrm{km}) \\
\text { Fertilizers, type and quantity (kg) } \\
\text { Phytosanitary products, type and } \\
\text { quantity (kg) }\end{array}$ & $\begin{array}{l}\text { Diesel } \\
\text { Wastewater, amount and pollution } \\
\text { parameters }(\mathrm{L}, \mathrm{g} / \mathrm{L}) \\
\text { Electricity }(\mathrm{kWh}) \\
\text { Refrigerant gases, type and } \\
\text { amount }(\mathrm{kg}) \\
\text { Wine additives, type and amount } \\
(\mathrm{kg}) \\
\text { Bottles, type of glass and weight } \\
\text { (kg/bottle, total } \mathrm{kg}) \\
\text { Wastes, type and amount }(\mathrm{kg})\end{array}$ \\
\hline
\end{tabular}

For corporate carbon footprinting in wineries, data is collected per year (from September the $1^{\text {st }}$ to August the $31^{\text {st }}$ ). As some wineries are much bigger than others, for comparability sake, in this paper data and results will be given per kg of grape, per hectare of cultivated land or per bottle of wine. However, these results must not be taken as product carbon footprints.

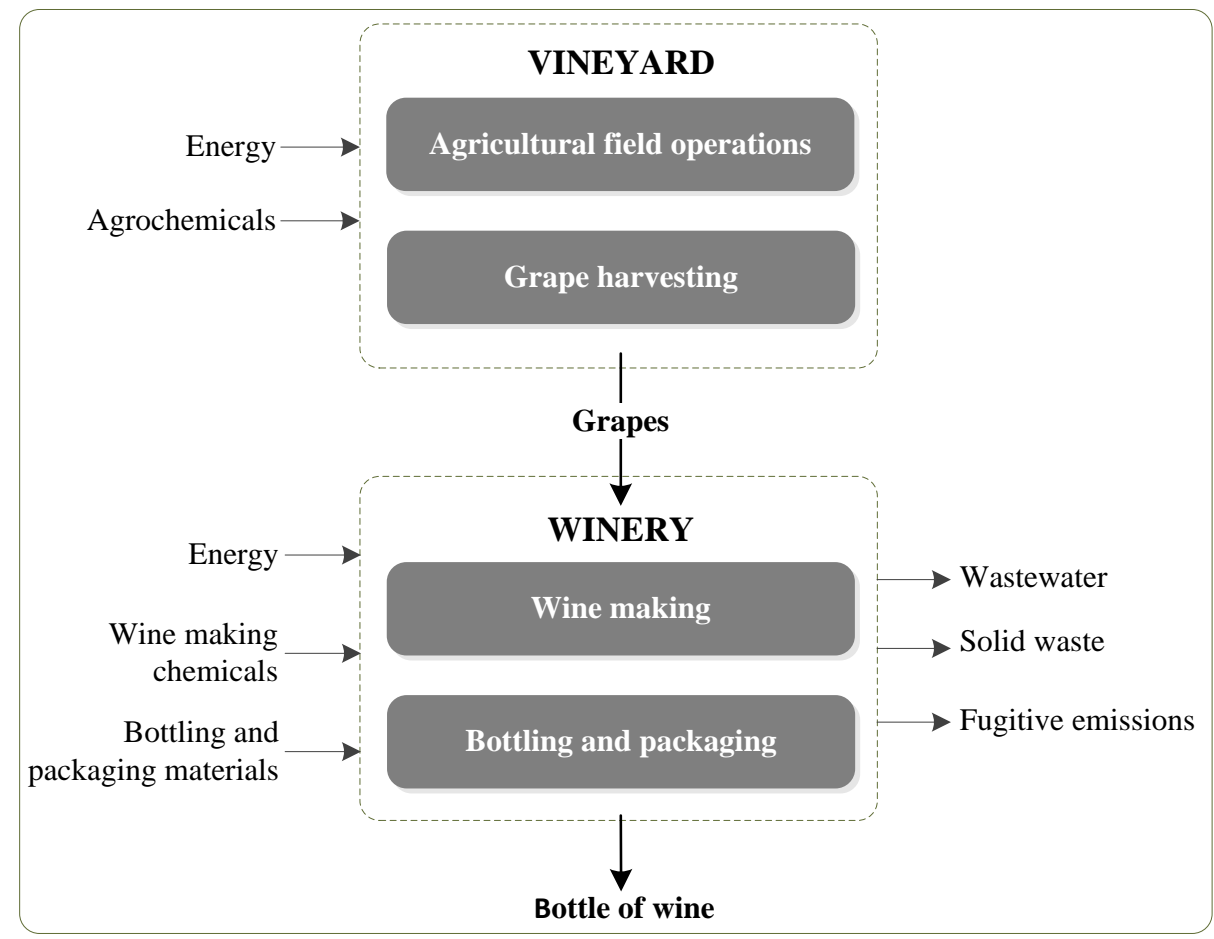

Figure 2. System boundaries and Flow diagram of the wine production system 
Table. 2. Characteristics of the wineries participating in the study

\begin{tabular}{|c|c|c|c|c|c|c|c|}
\hline $\begin{array}{l}\text { Winery } \\
\text { region }\end{array}$ & $\begin{array}{l}\text { Denomina- } \\
\text { tion of } \\
\text { origin } \\
\text { (DO) }\end{array}$ & $\begin{array}{l}\text { Total L of } \\
\text { wine } \\
\text { produced } \\
\text { per year }\end{array}$ & $\begin{array}{c}\text { Total } \\
\text { ha }\end{array}$ & $\begin{array}{l}\text { Total kg of } \\
\text { grape }\end{array}$ & Type of grape & $\begin{array}{l}\text { Type of } \\
\text { wine } \\
\text { produced in } \\
\text { the winery }\end{array}$ & $\begin{array}{c}\text { Source of } \\
\text { data }\end{array}$ \\
\hline \multirow[t]{2}{*}{$\begin{array}{l}\text { Galicia } \\
\text { (ES) }\end{array}$} & $\begin{array}{l}\text { Rías } \\
\text { Baixas }\end{array}$ & \multirow[t]{2}{*}{20000} & 2.8 & 32000 & albariño & white & $\begin{array}{l}\mathrm{CO} 2 \\
\text { Vino }\end{array}$ \\
\hline & $\begin{array}{l}\text { Rías } \\
\text { Baixas }\end{array}$ & & 3.5 & 38500 & albariño & white & $\begin{array}{l}\mathrm{CO} 2 \\
\text { Vino }\end{array}$ \\
\hline $\begin{array}{l}\text { Murcia } \\
\text { (ES) }\end{array}$ & Jumilla & 3391334 & & 6104088 & $\begin{array}{l}\text { Mourvèdre, cabernet sauvignon, } \\
\text { syrah, tempranillo, petit verdot, } \\
\text { macabeo, airén }\end{array}$ & $\mathrm{red} / \mathrm{white}$ & $\begin{array}{l}\mathrm{CO} 2 \\
\text { Vino }\end{array}$ \\
\hline \multirow[t]{2}{*}{$\begin{array}{l}\text { Catalonia } \\
\quad(\mathrm{ES})\end{array}$} & Penedes & 34441 & 24 & 120000 & $\begin{array}{l}\text { macabeo, chardonnay, riesling, } \\
\text { gewürztraminer, muscat, merlot, } \\
\text { parellada, xarello, pinot noir }\end{array}$ & $\begin{array}{l}\text { red/white/ro } \\
\text { se/sparkling }\end{array}$ & VINECO \\
\hline & $\begin{array}{l}\text { Costers del } \\
\text { Segre }\end{array}$ & 2645194 & 1865 & 16923500 & $\begin{array}{l}\text { chardonnay, cabernet sauvignon, } \\
\text { syrah, tempranillo, sauvignon blanc, } \\
\text { albariño, merlot, xarello, pinot noir }\end{array}$ & $\begin{array}{l}\text { red/white/ro } \\
\text { se/sparkling }\end{array}$ & VINECO \\
\hline \multirow{2}{*}{$\begin{array}{l}\text { Balearic } \\
\text { Islands - } \\
\text { Menorca } \\
\quad(E S)\end{array}$} & $\begin{array}{l}\text { Vi de la } \\
\text { Terra }\end{array}$ & 17000 & 4.5 & 25000 & merlot, chardonnay, syrah, muscat & $\begin{array}{l}\text { red/white/ro } \\
\text { se/sparkling }\end{array}$ & VINECO \\
\hline & $\begin{array}{l}\text { Vi de la } \\
\text { Terra }\end{array}$ & 60000 & 10 & 111000 & $\begin{array}{l}\text { merlot, chardonnay, syrah, cabernet } \\
\text { sauvignon, macabeo, tempranillo }\end{array}$ & $\begin{array}{l}\text { red/white/ro } \\
\text { se/sparkling }\end{array}$ & VINECO \\
\hline \multirow[t]{5}{*}{$\begin{array}{l}\text { Castilla la } \\
\text { Mancha } \\
\text { (ES) }\end{array}$} & Uclés & 596500 & 117 & 700000 & $\begin{array}{l}\text { tempranillo, chardonnay, cabernet, } \\
\text { sauvignon blanc, syrah, merlot }\end{array}$ & red/white & $\begin{array}{l}\mathrm{CO} 2 \\
\text { Vino }\end{array}$ \\
\hline & Uclés & 225000 & & & Tempranillo, macabeo & $\mathrm{red} / \mathrm{white}$ & $\begin{array}{l}\mathrm{CO} 2 \\
\text { Vino }\end{array}$ \\
\hline & Uclés & 16723417 & $\begin{array}{c}2462 . \\
3\end{array}$ & 21601847 & $\begin{array}{l}\text { Airén, tempranillo, chardonnay, } \\
\text { sauvignon blanc }\end{array}$ & $\mathrm{red} / \mathrm{white}$ & $\begin{array}{l}\mathrm{CO} 2 \\
\text { Vino }\end{array}$ \\
\hline & Uclés & 2564180 & 583.6 & 3663610 & $\begin{array}{l}\text { tempranillo, Cabernet-Sauvignon, } \\
\text { Syrah, Merlot, Sauvignon blanco } \\
\text { verdejo }\end{array}$ & $\mathrm{red} / \mathrm{white}$ & $\begin{array}{l}\mathrm{CO} 2 \\
\text { Vino }\end{array}$ \\
\hline & $\begin{array}{l}\text { Dehesa del } \\
\text { Carrizal }\end{array}$ & 56709 & 25 & 117875 & $\begin{array}{l}\text { tempranillo, chardonnay, cabernet } \\
\text { sauvignon, syrah, merlot, petit verdot }\end{array}$ & $\mathrm{red} / \mathrm{white}$ & $\begin{array}{l}\mathrm{CO} 2 \\
\text { Vino }\end{array}$ \\
\hline \multirow[t]{4}{*}{$\begin{array}{l}\text { Midi } \\
\text { Pyrenees } \\
\text { (FR) }\end{array}$} & $\begin{array}{l}\text { Gaillac/Côt } \\
\text { es du Tarn }\end{array}$ & 328600 & 67.2 & 41405 & $\begin{array}{l}\text { Sauvignon, mauzac, merlot, duras, } \\
\text { braucol, syrah, prunelard, gamay, } \\
\text { muscadelle, loin de l'oeil }\end{array}$ & $\begin{array}{l}\mathrm{red} / \mathrm{white} / \\
\text { rosé }\end{array}$ & VINECO \\
\hline & $\begin{array}{l}\text { Gaillac/Côt } \\
\text { es du Tarn }\end{array}$ & & 33.4 & 252180 & & & VINECO \\
\hline & $\begin{array}{l}\text { Gaillac/Côt } \\
\text { es du Tarn }\end{array}$ & 8907923 & & & $\begin{array}{l}\text { Sauvignon, mauzac, merlot, braucol, } \\
\text { syrah, gamay, muscadelle, loin de } \\
\text { l'oeil, Malbec, cabernet, cabernet } \\
\text { franc, négrette, tannat }\end{array}$ & $\begin{array}{l}\mathrm{red} / \mathrm{white} / \\
\text { rosé }\end{array}$ & VINECO \\
\hline & $\begin{array}{l}\text { Gaillac/Côt } \\
\text { es du Tarn }\end{array}$ & & 20 & 200733 & $\begin{array}{l}\text { muscat petit grain, muscat, syrah, } \\
\text { carignan, grenache, mourvèdre, } \\
\text { cinsault, cabernet franc, sauvignon, } \\
\text { cabernet sauvignon }\end{array}$ & & VINECO \\
\hline \multirow[t]{2}{*}{$\begin{array}{l}\text { Langedoc- } \\
\text { Rousillon } \\
\quad(\mathrm{FR})\end{array}$} & $\begin{array}{l}\text { Minervois, } \\
\text { Pays } \\
\text { d'Hérault }\end{array}$ & 31850 & 11.21 & 41405 & $\begin{array}{l}\text { syrah, cinsault, carignan, grenache } \\
\text { blanc, marsanne }\end{array}$ & $\begin{array}{l}\mathrm{red} / \mathrm{white} / \\
\text { rosé }\end{array}$ & VINECO \\
\hline & $\begin{array}{l}\text { Côtes du } \\
\text { Roussillon, } \\
\text { Côtes } \\
\text { Catalanes }\end{array}$ & 8119821 & & & $\begin{array}{c}\text { syrah, carignan, grenache blanc and } \\
\text { noir, roussanne, } \\
\text { chardonnay,macabeo, malvasie, } \\
\text { mourvèdre, merlot, muscat petit } \\
\text { grain and alexandrie }\end{array}$ & $\begin{array}{l}\mathrm{red} / \mathrm{white} / \\
\text { rosé }\end{array}$ & VINECO \\
\hline
\end{tabular}




\section{Results and Discussion}

\subsection{Inventory data for Vineyard subsystem}

This stage includes the agricultural field works: application of fertilizers, irrigation, phytosanitary treatments, harvesting of grapes and transportation of harvested grapes to the winery.

Aspects contributing to the environmental impacts of agriculture refer to the energy consumption and emissions derived from crop growing processes, such as the use of fertilizers, pesticides or herbicides. Many of these inputs are related to the area of cultivation. Thus, 1 hectare of vineyard or $1 \mathrm{~kg}$ of harvested grape could be both considered, in principle, good reference flows. The minimum, maximum, mean and standard deviation values obtained for the key processes in the vineyard stage are presented in Table 3.

Table 3. Values from 18 wineries per $\mathrm{kg}$ of grape and per ha of vineyard

\begin{tabular}{|c|c|c|c|c|c|c|c|c|}
\hline \multirow[b]{2}{*}{ Vineyard Inputs } & \multicolumn{4}{|c|}{ Per kg of grape } & \multicolumn{4}{|c|}{ Per ha of vineyards } \\
\hline & Min. & Max. & Mean & Std.dev. & Min. & Max. & Mean & Std.dev. \\
\hline \multicolumn{9}{|l|}{ Fertilizers } \\
\hline Organic fertilizer $[\mathrm{kg} \mathrm{N}]^{\mathbf{a}}$ & 0.00003 & 0.0102 & 0.0048 & \pm 0.0037 & 0.10 & 61.00 & 29.9 & \pm 26.7 \\
\hline Urea based synthetic fertilizer $[\mathrm{kg} \mathrm{N}]^{\mathbf{a}}$ & 0.002 & 0.006 & 0.0037 & \pm 0.0019 & 9.86 & 30.95 & 46.0 & \pm 17.4 \\
\hline $\begin{array}{l}\text { Phosphorous based synthetic fertilizer }[\mathrm{kg} \\
\left.\mathrm{P}_{2} \mathrm{O}_{5}\right]^{\mathrm{b}}\end{array}$ & 0.0036 & 0.0357 & 0.0114 & \pm 0.0137 & 20.00 & 213.70 & 70.1 & \pm 81.6 \\
\hline \multicolumn{9}{|l|}{ Phytosanitary products } \\
\hline Sulphur based fungicides $[\mathrm{kg}]$ & 0.00015 & 0.022 & 0.007 & \pm 0.008 & 0.72 & 175.31 & 42.92 & \pm 55.59 \\
\hline Unspecified fungicides [kg] & 0.00018 & 0.0046 & 0.002 & \pm 0.001 & 1.50 & 29.19 & 12.40 & \pm 11.94 \\
\hline Herbicides $[\mathrm{kg}]$ & 0.00021 & 0.0017 & 0.0007 & \pm 0.0005 & 1.49 & 10 & 5.19 & \pm 3.65 \\
\hline Insecticides [kg] & 0.00011 & 0.0009 & 0.0003 & \pm 0.0004 & 1.01 & 10 & 3.32 & \pm 4.45 \\
\hline \multicolumn{9}{|l|}{ Energy } \\
\hline Diesel [L] & 0.012 & 0.06 & 0.031 & \pm 0.015 & 44.61 & 474.84 & 221.2 & \pm 144.0 \\
\hline Electricity [kWh] & 0.0009 & 0.077 & 0.045 & \pm 0.028 & 10 & 568 & 352.4 & \pm 207.0 \\
\hline
\end{tabular}

From the present study, results show that inventory data per ha has a significantly higher deviation compared with data per $\mathrm{kg}$ of grape (see Table 3). This is likely due to the variation of agricultural fieldwork and application of agrochemicals, mostly depending on the intensity of the cultivation, measured as the number of vines planted per ha, which probably depends on the soil quality and climate conditions. Hence $1 \mathrm{~kg}$ of grape harvested is considered as the best reference flow to be used in our study and it is clearly related to the amount of wine obtained afterwards in the winery $(0.75 \mathrm{~L}$ wine/kg grape) (Báguena, 2014 and Calvo, 2014).

Electricity consumption in this phase is due to irrigation systems. Organic fertilizers used in vineyards are composed of compost and manure; therefore, as they are wastes from other production systems, no environmental burden will be assigned to their production when calculating the carbon footprint (GHG product protocol, 2011). Urea and phosphoric acid have been taken as proxies for calculation whenever synthetic fertilizers were reported, depending on whether they contain nitrogen or phosphorous in their chemical composition. For phytosanitary products a generic phytosanitary was used as a proxy, but in the case of sulphur based products, sulphur production was used. 


\subsection{Inventory data for Winery subsystem}

This subsystem includes wine production, bottling and packaging processes. Processing $1 \mathrm{~kg}$ of grape yields $0.75 \mathrm{~L}$ of wine, which is equivalent to one standard bottle of wine (Báguena, 2014 and Calvo, 2014). The reference flow of this winery stage was defined as a $0.75 \mathrm{~L}$ bottle of wine. Results are shown in Tables 4 and 5.

Table 4. Inventory data for wine additives related to production of $0.75 \mathrm{~L}$ of wine

\begin{tabular}{|c|c|c|c|c|c|}
\hline \multicolumn{2}{|l|}{ Input } & \multicolumn{4}{|c|}{ 0.75 L wine (standard bottle) } \\
\hline Categories & Products $[\mathrm{kg}]$ & Minimum & Maximum & Mean & Std.dev. \\
\hline \multirow[t]{2}{*}{ Filtering material } & Perlite & 0.0045 & 0.01725 & 0.011 & \pm 0.009 \\
\hline & Various* & 0.00004 & 0.01125 & 0.003 & \pm 0.004 \\
\hline \multirow{2}{*}{ Clarifying material } & Bentonite & 0.00028 & 0.00064 & 0.0005 & \pm 0.0002 \\
\hline & Various* & $7.85 \mathrm{E}-06$ & 0.00213 & 0.0007 & \pm 0.0007 \\
\hline \multirow[t]{2}{*}{ Antioxidants } & Sulphur & $4.12 \mathrm{E}-06$ & 0.0015 & 0.0007 & \pm 0.0007 \\
\hline & Various $^{*}$ & $1.32 \mathrm{E}-05$ & 0.00141 & 0.00045 & \pm 0.00061 \\
\hline \multirow[t]{2}{*}{ Stabilizers } & Polyvinylpolypyrrolidone ${ }^{* *}$ & - & - & 0.00005 & - \\
\hline & Various* ${ }^{*}$ & 0.000055 & 0.00067 & 0.0003 & \pm 0.0003 \\
\hline Carbon dioxide & Carbon dioxide & 0.000051 & 0.00262 & 0.0008 & \pm 0.0012 \\
\hline \multirow[t]{2}{*}{ Acidifiers } & Citric acid & 0.000005 & 0.00044 & 0.00014 & \pm 0.00016 \\
\hline & Various* & 0.00002 & 0.00033 & 0.00017 & \pm 0.00022 \\
\hline Microfiltering material & Oxygen & 0.000011 & 0.000016 & 0.000013 & \pm 0.000003 \\
\hline Disinfectants & Chloride & $1.01 \mathrm{E}-06$ & 0.000050 & 0.000025 & \pm 0.000035 \\
\hline \multirow[t]{2}{*}{ Detergents } & Caustic soda & 0.00009 & 0.00022 & 0.00016 & \pm 0.00010 \\
\hline & Various $^{*}$ & 0.00022 & 0.00067 & 0.00322 & \pm 0.00023 \\
\hline Nitrogen $^{*}$ & & - & - & 0.00004 & - \\
\hline \multirow{2}{*}{ Fermentation products } & Ammonium phosphate & 0.000022 & 0.000202 & 0.00015 & \pm 0.00008 \\
\hline & Various* ${ }^{*}$ & 0.00012 & 0.012 & 0.00315 & \pm 0.00592 \\
\hline
\end{tabular}

Chemical assimilated to the one named above in the same product category.

*** Single available data

Table 5. Inventory data in winery (without wine additives, which are shown in Table 4) related to production of $0.75 \mathrm{~L}$ of wine.

\begin{tabular}{|c|c|c|c|c|c|}
\hline \multicolumn{2}{|l|}{ Inputs } & \multicolumn{4}{|c|}{ Per $0.75 \mathrm{~L}$ of wine } \\
\hline \multirow{4}{*}{ Products $[\mathrm{kg}]$} & Hard Plastic ${ }^{* *}$ & - & - & 0.00004 & \\
\hline & Plastic sheet (Bag in box) & 0.0008 & 0.0032 & 0.0018 & \pm 0.0009 \\
\hline & Glass & 0.054 & 0.774 & 0.349 & \pm 0.242 \\
\hline & Cardboard & 0.0034 & 0.0525 & 0.0289 & \pm 0.0167 \\
\hline \multicolumn{6}{|l|}{ Energy } \\
\hline & Diesel for transportation vehicles [L] & 0.0002 & 0.0132 & 0.0065 & \pm 0.0065 \\
\hline & $\begin{array}{l}\text { Diesel for heating, water heating. } \\
\text { process equipment [L] }\end{array}$ & 0.00004 & 0.024375 & 0.0117 & \pm 0.0107 \\
\hline & Electricity $[\mathrm{kWh}]$ & 0.1193 & 1.8075 & 0.4425 & \pm 0.4993 \\
\hline \multicolumn{6}{|l|}{ Wastes } \\
\hline & Waste water $\left[\mathrm{m}^{3}\right]$ & 0.00072 & 0.0105 & 0.0034 & \pm 0.0033 \\
\hline & Solid waste $[\mathrm{kg}]$ & 0.00075 & 0.0375 & 0.0135 & \pm 0.0140 \\
\hline & Residual glass $[\mathrm{kg}]$ & 0.00001 & 0.984 & 0.1515 & \pm 0.3675 \\
\hline \multicolumn{6}{|l|}{ Refrigerant gas recharge [kg] } \\
\hline Fugitive emissions** & $\mathrm{R} 22$ & - & - & $8.48 \mathrm{E}-06$ & - \\
\hline & R410a & - & - & $1.21 \mathrm{E}-05$ & - \\
\hline & $\mathrm{R} 407$ & - & - & $1.70 \mathrm{E}-06$ & - \\
\hline
\end{tabular}

Assimilated to natural gas due to lack of information on the type of the gas

** Single available data 
Electricity and glass consumption are the most significant issues by far (see Table 5). The amount of refrigerant gases recharge is very low, but it may have an important contribution to the carbon footprint.

\subsection{Average carbon footprint results}

Carbon footprint calculations from inventory data, both for vineyard and winery stages (Figure 1), were performed by using $\mathrm{CO}_{2}$-eq emission factors. For data associated with the production of chemicals, these factors were taken from the GaBi6 professional database (Thinkstep, 2015); and for data related to other processes, such as direct and indirect $\mathrm{N}_{2} \mathrm{O}$ soil emissions from synthetic and organic fertilisers or waste treatment, emission factors were obtained from IPCC 2007. They were calculated according to country and region specific characteristics.

The chosen global reference unit (RU) for the study has been one bottle of $0.75 \mathrm{~L}$ of wine (which connects directly with the reference flows of both subsystems). Figure 3 shows the contribution of each stage within the overall average carbon footprint, which has been obtained as $0.85 \mathrm{~kg} \mathrm{CO}_{2}$-eq per RU. The results have been obtained using the average data for the 18 wineries studied. Figure 4 shows the main contributors of greenhouse gass (GHG) emissions to each subsystem: vineyard and winery.

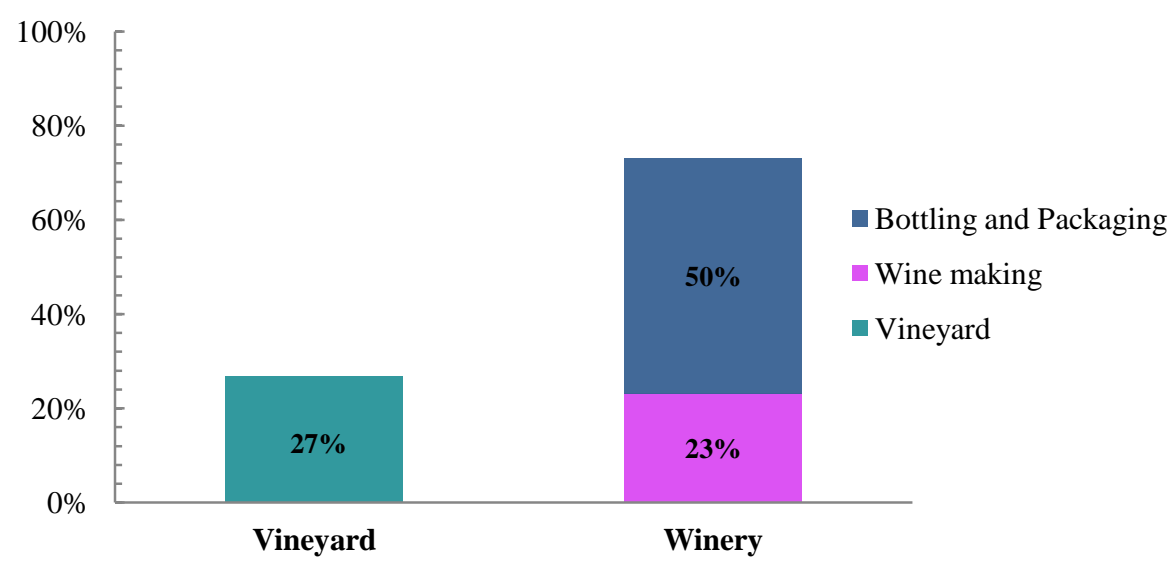

Figure 3. Relative contribution of vineyard and winery subsystems to GHG emissions per RU. 


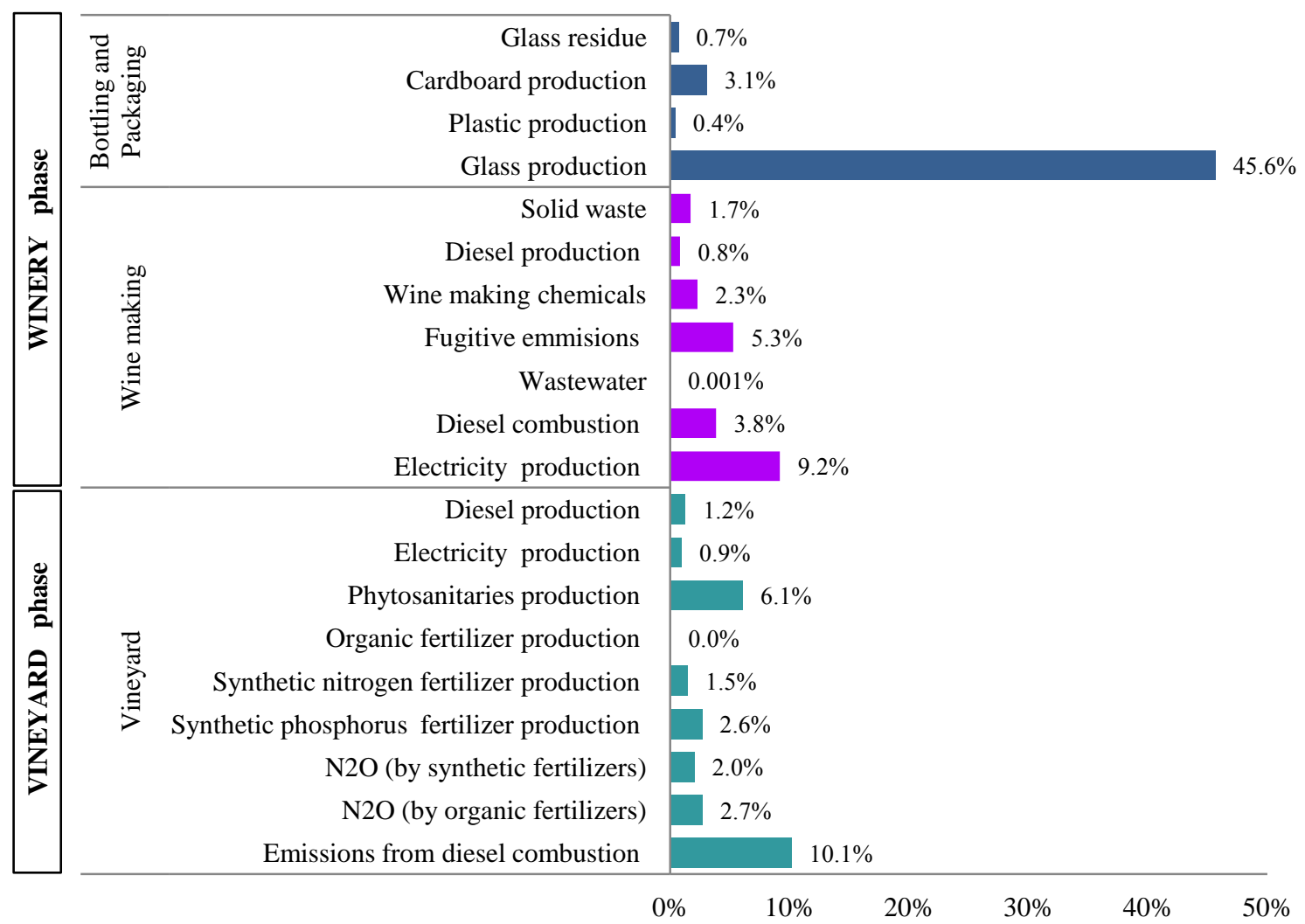

Figure 4 Relative contribution of the different processes to GHG emissions to the RU.

Bottling and packaging processes have a significant influence on the environmental performance of the overall winery subsystem, contributing to $50 \%$ of the GHG emissions (see Figure 3). The main contributor in this process is the production of glass, with an average contribution of $45.6 \%$ to the total carbon footprint, which is consistent with the results obtained by other researchers (Bosco et al., 2011; Fusi et al., 2014).

Electricity consumption and fugitive emissions appear as the subsequent largest contributors in the winery phase, adding on average 9.2\% and 5.3\% respectively (Figure 4). As seen from the results, wine additive products have a low influence. This may be due to the use of simpler proxy substances from LCA databases in order to find emission factors, instead of performing a life cycle assessment of each one of the more sophisticated chemicals used in wine making.

In the vineyards, GHG emissions are mainly associated with the combustion of diesel for agricultural field works, which is consistent with the previously reported studies in the recent literature (Benedetto, 2013; Villanueva-Rey et al., 2014). The emissions derived from combustion of diesel and production of phytosanitary substances are the most burdening processes in this phase, with an average relative contribution of $10 \%$ and $6 \%$ respectively to the carbon footprint (see Figure 4). The smallest GHG emission contribution in the vineyard comes from the production of electricity used for the irrigation of grapes. It has to be said that diesel is the main source of energy used for irrigation, not electricity.

As previously stated, both good and inefficient practices have been identified in the surveyed wineries. Table 6 presents the best and worst case results expressed in terms of $\mathrm{kg} \mathrm{CO}_{2}$-eq per RU. These results come from converting the inventory data into GHG emissions by using the correspondent emission factors. 
Table 6 Benchmarks for contribution of each wine production process to the carbon footprint of $0.75 \mathrm{~L}$ of wine.

\begin{tabular}{|c|c|c|c|}
\hline Vineyard & $\begin{array}{c}\text { Min. } \\
{[\mathrm{kg} \mathrm{CO} \text {-eq] }}\end{array}$ & $\begin{array}{c}\text { Max. } \\
{[\mathrm{kg} \mathrm{CO} \text {-eq] }}\end{array}$ & $\begin{array}{c}\text { Mean } \\
{\left[\mathrm{kg} \mathrm{CO} \mathrm{CO}_{2} \text {-eq] }\right.}\end{array}$ \\
\hline \multicolumn{4}{|l|}{ Input } \\
\hline Diesel production & 0.004 & 0.021 & 0.011 \\
\hline Electricity production & 0.0002 & 0.014 & 0.008 \\
\hline Production of phytosanitary substances & 0.017 & 0.355 & 0,052 \\
\hline Production of urea based fertilizers & 0.0053 & 0.02 & 0.012 \\
\hline Production of phosphor based fertilizers & 0.0089 & 0.045 & 0.022 \\
\hline \multicolumn{4}{|l|}{ Output } \\
\hline $\begin{array}{l}\text { Emissions from diesel combustion for agricultural } \\
\text { field operations }\end{array}$ & 0.033 & 0.167 & 0.086 \\
\hline $\mathrm{N}_{2} \mathrm{O}$ from application of organic fertilizers & 0.0001 & 0.048 & 0.023 \\
\hline $\mathrm{N}_{2} \mathrm{O}$ from application of synthetic fertilizers & 0.0094 & 0.028 & 0.017 \\
\hline Total vineyard & 0.08 & 0.70 & 0.23 \\
\hline Winery & $\begin{array}{c}\text { Min. } \\
{[\mathrm{kg} \mathrm{CO} \text {-eq] }}\end{array}$ & $\begin{array}{c}\text { Max. } \\
{[\mathrm{kg} \mathrm{CO} \text {-eq] }}\end{array}$ & $\begin{array}{c}\text { Mean } \\
{\left[\mathrm{kg} \mathrm{CO} \mathrm{CO}_{2} \text {-eq] }\right.}\end{array}$ \\
\hline \multicolumn{4}{|l|}{ Input } \\
\hline Electricity production & 0.0212 & 0.3216 & 0.0783 \\
\hline Cardboard production & 0.0031 & 0.0469 & 0.0261 \\
\hline Plastic production & 0.0016 & 0.0059 & 0.0035 \\
\hline Glass production & 0.0602 & 0.8633 & 0.3893 \\
\hline Diesel production & 0.0001 & 0.0143 & 0.0069 \\
\hline Detergents & 0.0004 & 0.0011 & 0.0043 \\
\hline Clarifying materials & 0.0001 & 0.0014 & 0.0006 \\
\hline Oxygen & $1.11 \mathrm{E}-06$ & $1.62 \mathrm{E}-06$ & $1.31 \mathrm{E}-06$ \\
\hline Fermentation products & 0.0001 & 0.0122 & 0.0033 \\
\hline Acidifiers & 0.00014 & 0.00422 & 0.0017 \\
\hline Antioxidants & 0.00001 & 0.00185 & 0.0007 \\
\hline Stabilizers & 0.0003 & 0.0032 & 0.0017 \\
\hline Carbon dioxide & 0.00002 & 0.00125 & 0.00038 \\
\hline Disinfectants & $1.28 \mathrm{E}-06$ & $6.40 \mathrm{E}-05$ & $3.20 \mathrm{E}-05$ \\
\hline Nitrogen & $2.42 \mathrm{E}-06$ & $2.42 \mathrm{E}-06$ & $2.42 \mathrm{E}-06$ \\
\hline Filtering materials & 0.00220 & 0.01367 & 0.00684 \\
\hline \multicolumn{4}{|l|}{ Output } \\
\hline Glass residues & $4.81 \mathrm{E}-07$ & 0.0364 & 0.0056 \\
\hline Municipal Solid waste & 0.0007 & 0.0386 & 0.0144 \\
\hline Fugitive emissions & 0 & 0.045 & 0.045 \\
\hline Waste water & $1.01 \mathrm{E}-06$ & $1.55 \mathrm{E}-05$ & $4.78 \mathrm{E}-06$ \\
\hline \multirow[t]{2}{*}{ Emissions from diesel combustion } & 0.0001 & 0.0681 & 0.0326 \\
\hline & 0.09 & 1.48 & 0.62 \\
\hline A bottle of $(0.75 \mathrm{~L})$ wine & 0.17 & 2.18 & 0.85 \\
\hline
\end{tabular}

Taking the universe of wineries studied and shown in Table 2, the mean winery would produce $3,886,397$ bottles of $0.75 \mathrm{~L}$ of wine per year, and the mean vineyard would produce 3,331,543 $\mathrm{kg}$ of grapes. The amount of wine is higher than the amount which would come from harvest, as the wineries buy grapes and wine from other sources to complement the wine production. 
The carbon footprint values of investigated wineries per RU $(0.75 \mathrm{~L}$ of wine) in the present study are found in the range between 0.17 and $2.18 \mathrm{~kg} \mathrm{CO}_{2}$-eq, the average being $0.85 \mathrm{~kg} \mathrm{CO}_{2}$-eq/bottle of wine. In current literature, product carbon footprint (cradle-to-gate) per bottle of wine ranges from 0.6 to 2.68 kg CO${ }_{2}$-eq (Bosco et al., 2011; Point 2008; Neto et al., 2013; Gazulla et al., 2010; Fusi et al., 2014). The minimum value obtained in this study falls below the reported range, but as will be explained later, is not achievable by all wineries. On the other hand maximum value is comparable with current literature.

The vineyard phase is the one presenting a wider variation. Carbon footprint results of the vineyard phase from previously published studies (Marras, S., et al., 2015; Fusi et al., 2014; Vázquez-Rowe et al., 2012a) are in the range of $0.169-2.5 \mathrm{~kg} \mathrm{CO}_{2}$-eq/bottle and our average value fits within the lower side of $0.23 \mathrm{~kg} \mathrm{CO}_{2}$-eq/bottle.

\subsection{Best scenario results}

The results have shown that the most contributing aspects are:

i. In the vineyard phase: combustion due to field works (10\% contribution) and phytosanitary products use $(6 \%)$.

ii. In the winery phase: production of glass (46\%) and production of electricity (9\%).

The benchmark values obtained from wineries reveal that, establishing best practices and with better resource consumption (diesel and phytosanitaries in the vineyard and weight of glass-bottle and electricity consumption in the winery), the carbon footprint could be about $0.64 \mathrm{~kg} \mathrm{CO}_{2}$-eq per bottle, achieving a reduction of $25 \%$. This result was obtained by using the minimum values of the 4 most contributing aspects, reported in the inventory data from wineries (see Figure 5). In the case of glass production, a bottle of $300 \mathrm{~g}$ of glass (the lightest one from our study) was used as the minimum weight for a glass bottle in the wine sector (lower than the one resulting from the average values, which was $350 \mathrm{~g} / \mathrm{bottle}$ ).

It has to be mentioned that the complete set of minimum values reported probably cannot be achieved by any winery, because there are aspects related to climate and grape characteristics that can affect the consumptions. For example, the minimum amount of phytosanitary products reported (mainly fungicides) in this study corresponds to a winery located in Castilla La Mancha (centre of Spain), which is a dry climate region, a condition which prevents pests and, therefore, needs less fungicides than those required in a wet climate (Báguena, 2014). Thus, this minimum value of carbon footprint could not be achievable by any winery and should only be seen as an ideal.

On the other hand, in the winery phase, the reduction of glass and electricity consumption could be applied by all wineries, because these inputs are not affected by external aspects. 


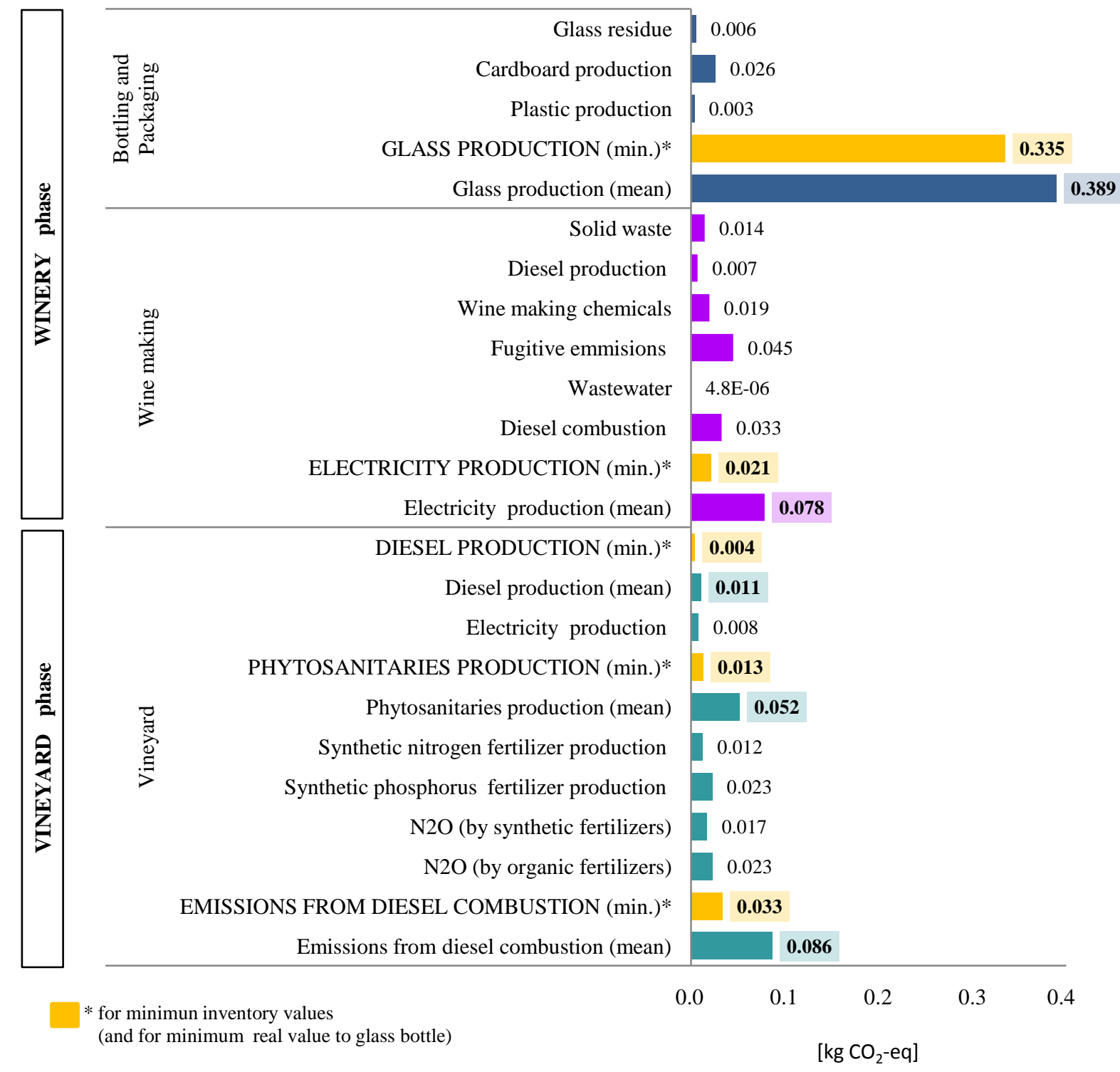

Figure 5. Comparison of average values of carbon footprint (in $\mathrm{kg} \mathrm{CO}_{2}$-eq) with some minimum consumptions reported.

\subsection{Recommendations for process improvement}

Some Eco-innovation actions that can be implemented to improve the environmental profile of wine and to reduce the carbon footprint are suggested, considering the findings of this study and other wine related studies in the literature (Table 7).

Taking into account the findings obtained from the current study, reasonable improvement options to reduce the environmental impact of wine making would be: the reduction of glass weight and the reduction of the use of phytosanitary products, which are the identified critical hotspots. Another recommendation would be to obtain more accurate individual inventory data, so that the results would 
be as closer as possible to reality for each winery. They have more accurate data on inputs and outputs from the winery phase than from the vineyard phase, the latter being less important.

Table 7. Some measures for process Eco-innovation.

\begin{tabular}{|c|c|c|}
\hline Issues & Improvement opportunities & References \\
\hline \multirow{2}{*}{$\begin{array}{c}\text { Energy } \\
\text { (in vineyard) }\end{array}$} & - Monitor and record water and energy use. & Our study \\
\hline & $\begin{array}{l}\text { - Inclusion of measures to reduce the energy intensity of field works by using } \\
\text { efficient machinery and reducing the depth of soil works up to necessary. }\end{array}$ & Our study \\
\hline \multirow{2}{*}{$\begin{array}{l}\text { Fertilizers and } \\
\text { phytosanitaries } \\
\text { (in vineyard) }\end{array}$} & $\begin{array}{l}\text { - Ecological grape growing, reducing agrochemical use or substituting them } \\
\text { with other less harmful ones }\end{array}$ & $\begin{array}{l}\text { Our study; Aranda } \\
\text { et al., } 2005\end{array}$ \\
\hline & $\begin{array}{l}\text { - Avoid chemicals remains being left inside the tank at the end of the } \\
\text { application (of fertilizers and phytosanitary products) by adding water and } \\
\text { spraying the diluted solution in the field. This will avoid overconsumption } \\
\text { and prevent wastewater generation. }\end{array}$ & Our study \\
\hline \multirow[t]{3}{*}{$\begin{array}{c}\text { Energy } \\
\text { (in winery) }\end{array}$} & $\begin{array}{l}\text { - Reuse of hot water resulting from bottling sterilization process for } \\
\text { secondary rinses or other activities that require hot water. It also offers } \\
\text { savings on water usage, and reduces the quantity of wastewater generated }\end{array}$ & $\begin{array}{l}\text { Malkin and Bahner, } \\
1999\end{array}$ \\
\hline & - Use of cleaner alternatives to diesel. & Benedetto, 2013 \\
\hline & - Use of electricity with a higher portion of renewable sources. & Our study \\
\hline \multirow[t]{2}{*}{$\begin{array}{l}\text { Water } \\
\text { consumption } \\
\quad \text { and } \\
\text { Wastewater } \\
\text { (in winery) }\end{array}$} & $\begin{array}{l}\text { - Scraping off pipes during transfer operations in the winery (or pigging, very } \\
\text { common in agrifood) can reduce water consumption as well as wastewater } \\
\text { pollution by recovering products and avoiding mixtures. This technology } \\
\text { has been recently adapted to wineries by Inoxpa and tests conducted by } \\
\mathrm{IFV}^{4} \text { show a } 50-80 \% \text { reduction of water consumption of winery transfer } \\
\text { operations. }\end{array}$ & Our study \\
\hline & $\begin{array}{l}\text { - Wastewater from the cellar can be managed in a better way by applying it to } \\
\text { artificial wetlands (with less energy consumption than other treatments). }\end{array}$ & Our study \\
\hline \multirow[t]{2}{*}{$\begin{array}{l}\text { Glass } \\
\text { consumption } \\
\text { (in winery) }\end{array}$} & $\begin{array}{l}\text { - Use of lighter bottles, with less material but the same mechanical resistance. } \\
\text { In the brewing sector, the weight of the bottles has been reduced } \\
\text { progressively to less than half. }\end{array}$ & $\begin{array}{l}\text { Our study; Ardente } \\
\text { et al., 2006; Point, } \\
\text { 2008; Point et al., } \\
\text { 2012; Colman \& } \\
\text { Päster, 2009; } \\
\text { Amienyo et al., } \\
2014\end{array}$ \\
\hline & - Changing the design of the bottles by using other materials instead of glass. & $\begin{array}{lll}\text { Amienyo et. Al. } \\
2014\end{array}$ \\
\hline \multirow[t]{2}{*}{$\begin{array}{l}\text { Glass waste } \\
\text { management }\end{array}$} & - Increasing recycling rate of bottles at source. & $\begin{array}{l}\text { Our study; } \\
\text { Amienyo et al., } \\
2014\end{array}$ \\
\hline & - Reuse of bottles, when possible. & Aranda et al., 2005. \\
\hline
\end{tabular}

\footnotetext{
${ }^{4}$ Within the EU Project Winenvironment (http://www.winenvironment.eu/)
} 


\section{Conclusions}

In this paper, a statistical analysis of the data collected from 18 wineries is presented. Data per hectare of vineyards and per $\mathrm{kg}$ of grapes was statistically analysed, showing that inventory data per $1 \mathrm{~kg}$ of grape has a much lower standard deviation.

Data used is of good quality, it covers small and large wineries in a large geographical area and also has precision, completeness and methodological coverage. The variability of data values is normal due to process specificities, depending on the region, climate and type of end product wine. It is the most detailed and wide-ranging paper found in literature showing corporate inventory data from 18 sites including both, vineyard and winery, with the same system boundaries, year studied and hypothesis.

The hotspots contributing to the carbon footprint of wine were highlighted, glass production for bottling being the most important one.

The main novelty of this paper is the corporate carbon footprint approach, only twice reported previously in the wine sector, on one occasion without presenting inventory data (Penela, et al., 2009) and the other from a single vineyard in Italy (Marras, S., et al., 2015). This is a very convenient approach to push SME companies towards Eco-innovation and sustainability because it is easier for them to understand and apply.

Room for Eco-innovation has been found, as inventory data presented here will enable wineries to compare their own data with the average presented and to identify the most relevant aspects to their carbon footprint, as well as, potential improvements.

The main drawbacks and limitations of the study are the systematic truncation errors due to the bottom-up process approach and the limited number of indirect GHG emissions (scope 3 categories) included.

\section{Acknowledgements}

This study was coordinated by Cyclus Vitae Solutions in the framework of both the "CO2 vino" project, co-funded by the European Social Fund through the Empleaverde Programme by the Spanish Fundación Biodiversidad with the objective of improving the competitiveness of SMEs within the wine sector; and the VINECO project, funded by the Euroregion Pyrenees-Mediterranean with the objective of improving the wine sector's sustainability.

The authors wish to thank the funding institutions and the researchers from partners and subcontractors within the "CO2 vino" project (Cyclus Vitae Solutions, Fundación Empresa y Clima, Universidad Politécnica de Madrid and the UNESCO Chair in Life cycle and Climate Change ESCIUPF) and the VINECO project (Cyclus Vitae Solutions, Chamber of Commerce of Menorca, Institut Français de la Vigne et du Vin and the UNESCO Chair). 


\section{References}

Amienyo, D., Camilleri, C., Azapagic, A., 2014. Environmental impacts of consumption of Australian red wine in the UK. J. Clean. Prod. 72, 110-119.

Aranda, A., Zabalza, I., Scarpellini, S., 2005. Economic and environmental analysis of the wine bottle production in Spain by means of life cycle assessment. Int. J. Agric. Resour. Gov. Ecol. 4, 178-191.

Ardente, F., Beccali, G., Cellura, M., Marvuglia, A., 2006. POEMS: A case study of an Italian wine-producing firm. Environ. Manage. 38, 350-364.

Arzoumanidis I., Fullana-i-Palmer P., Raggi A., Gazulla C., Raugei M., Benveniste G., Anglada M., 2014. Unresolved issues in wine carbon footprint accounting. Journal of Cleaner Production, Volume 82, 1 November 2014, Pages 16-22.

Báguena, F., 2014. Winemaking and vineyard specialist on Apellation Cariñena, Aragón, Spain. Personal communication.

Baitz M., Albrecht S., Brauner E., Broadbent C., Castellan G., Conrath P., Fava J., Finkbeiner M., Fischer M., Fullana-i-Palmer P., Krinke S., Leroy C., Loebel O., McKeown P., Mersiowsky I., Möginger B., Pfaadt M., Rebitzer G., Rother E., Ruhland k., Schanssema A., Tikana L., 2013. LCA's theory and practice: like ebony and ivory living in perfect harmony? The International Journal of Life Cycle Assessment, 18(1):5-13

Bala A., Raugei M., Benveniste G., Gazulla C., Fullana-i-Palmer P., 2010. Simplified tools for Global Warming Potential evaluation: when 'good enough' is best. The International Journal of Life Cycle Assessment, 15(5):489-498.

Bellon-Maurel, V., Peters, G.M., Clermidy, S., Frizarin, G., Sinfort, C., Ojeda, H., Roux, Ph., Short, M.D., 2015. Streamlining life cycle inventory data generation in agriculture using traceability data and information and communication technologies - part II: application to viticulture. J. Clean. Prod. 87, 119-129

Benedetto, G., 2013. The environmental impact of a Sardinian wine by partial Life Cycle Assessment. Wine Econ. Policy 2, 33-41.

Benedetto G., Rugani B., Vázquez-Rowe I., 2014. Rebound effects due to economic choices when assessing the environmental sustainability of wine. Food Policy 49, 167-173.

Bosco, S., Di Bene, C., Galli, M., Remorini, D., Massai, R., Bonari, E., 2011. Greenhouse gas emissions in the agricultural phase of wine production in the Maremma rural district in Tuscany. Italy. Ital. J. Agron. 6, 93100.

Reference Document on Best Available Techniques (BREF) in the Food, drink and milk industries. European Comission, August 2006. http://eippcb.jrc.ec.europa.eu/reference/BREF/fdm_bref_0806.pdf

Bullard, C.W., P.S. Penner and D.A. Pilati (1978) Net energy analysis - handbook for combining process and input-output analysis. Resources and Energy 1, 267-313.

Calvo, P., 2014. Oenologist, Viñedos y Bodegas Alconde S.L., Navarra, Spain, Personal communication.

Cholette, S., Venkat, K., 2009. The energy and carbon intensity of wine distribution: A study of logistical options for delivering wine to consumers. J. Clean. Prod. 17, 1401-1413.

Colman, T., Päster, P., 2009. Red, White, and "Green": The Cost of Greenhouse Gas Emissions in the Global Wine Trade. J. Wine Res. 20, 15-26.

DIRECTIVE 2003/87/EC. Establishing a scheme for greenhouse gas emission allowance trading within the Community.

Forbes, S.L., Cohen, D. a., Cullen, R., Wratten, S.D., Fountain, J., 2009. Consumer attitudes regarding environmentally sustainable wine: an exploratory study of the New Zealand marketplace. J. Clean. Prod. 17, 1195-1199.

Fusi, A., Guidetti, R., Benedetto, G., 2014. Delving into the environmental aspect of a Sardinian white wine: From partial to total life cycle assessment. Sci. Total Environ. 472, 989-1000.

Gazulla, C., Raugei, M., Fullana-i-Palmer, P., 2010. Taking a life cycle look at crianza wine production in Spain: where are the bottlenecks?. Int. J. Life Cycle Assess. 15, 330-337.

GHG Protocol corporate (2004). A Corporate Accounting and Reporting Standard. World Resources Institute and World Business Council for Sustainable Development, March 2004. ISBN 1-56973-568-9.

GHG Protocol corporate (2011). Corporate Value Chain (Scope 3) Accounting and Reporting Standard. World Resources Institute and World Business Council for Sustainable Development, September 2011. ISBN 9781-56973-772-9.

GHG Protocol for products (2011). Product Life Cycle Accounting and Reporting Standard. World Resources Institute and World Business Council for Sustainable Development, September 2011. ISBN 978-1-56973773-6.

Gibbons, J.C., A.M. Wolsky and G. Tolley (1982) Approximate aggregation and error in input-output models. Resources and Energy 4, 203-230. 
Heijungs, R. and S. Suh (2002) The computational structure of life cycle assessment. Dordrecht, Netherlands, Kluwer Academic Publishers.

Iannone R., Miranda S., Riemma S., De Marco I., 2016. Improving environmental performances in wine production by a life cycle assessment analysis. J. Clean. Prod. 111, 172-180.

IPCC 2007. Intergovernamental Panel on Climate Change. Emission Factors database. http://www.ipccnggip.iges.or.jp/EFDB/main.php.

ISO 14040, 2006. Environmental Management-Life Cycle Assessment-Principles and Framework. International Organization for Standardization, Geneva, Switzerland.

ISO 14044, 2006. Environmental Management-Life Cycle Assessment-Requirements and Guidelines. International Organization for Standardization, Geneva, Switzerland.

ISO 14064, 2006. Greenhouse gases -- Part 1: Specification with guidance at the organization level for quantification and reporting of greenhouse gas emissions and removals. International Organization for Standardization, Geneva, Switzerland.

ISO 14067, 2013. Greenhouse gases - Carbon footprint of products - Requirements and guidelines for quantification and communication," International Organization for Standardization, Geneva, Switzerland.

IWCC, International Wine Carbon Calculator, The Wine Institute of California, New Zealand Winegrowers, Integrated Production of Wine South Africa and the Winemakers Federation of Australia, http://www.wineinstitute.org/ghgprotocol.

Kymn, K., 1990. Aggregation in input-output models: a comprehensive review, 1946-71. Economic Systems Research 2, 65-93.

Lenzen, M., 2000. Errors in conventional and input-output-based life-cycle inventories. Journal of Industrial Ecology 4, 127-148.

Lenzen, M., 2011. Aggregation versus disaggregation in input-output analysis of the environment. Economic Systems Research 23, $73-89$.

Lenzen, M. and C.J. Dey, 2000. Truncation error in embodied energy analyses of basic iron and steel products. Energy 25, 577-585.

Lenzen, M. and G. Treloar, 2002. Energy embodied in buildings: wood versus concrete. Energy Policy 30, 249255.

Lenzen, M. and G. Treloar, 2003. Differential convergence of life-cycle inventories towards upstream production layers. Journal of Industrial Ecology 6, 137-160.

LIFE 08 ENV/E/000143. Haprowine: Integrated waste management and life cycle assessment in the wine industry: from wate to high-value products. 2010-2013.

Malkin-Webber, M., Bahner, M., 1999. Pollution prevention for the wine industry. Research Triangle Institute. http://www.greenbiz.com/sites/default/files/document/O16F2388.pdf

Mapbox Maps, 2015. Retrieved from http://www.mapbox.com.

Marras S., Masia S., Ducec P., Spanoa D., SircaC., 2015. Carbon footprint assessment on a mature vineyard. Agric. and Forest Meteorol. 214-215, 350-356.

Moskowitz, P.D. and M.D. Rowe, 1985. A comparison of input-output and process analysis. In: P.F. Ricci and M.D. Rowe (eds.) Health and Environmental Risk Assessment. New York, NY, USA, Pergamon Press, 281 293.

Murray, A.T., 1998. Minimizing aggregation error in input-output models. Environment and Planning A 30 , $1125-1128$

Neto, B., Dias, A.C., Machado, M., 2013. Life cycle assessment of the supply chain of a Portuguese wine: From viticulture to distribution. Int. J. Life Cycle Assess. 18, 590-602.

OIV, 2012. Statistical Report on world vitiviniculture: perspectives and trends. http://www.oiv.int/oiv/cms/ index?rub ric $\mathrm{Id}=44538631-7 \mathrm{ad} 2-49 \mathrm{cb}-9710-\mathrm{ad} 5 \mathrm{~b} 957296 \mathrm{c} 7$.

PAS 2050, 2011. Specification for the assessment of the life cycle greenhouse gas emissions of goods and services. British Standards Institution (BSI), London, UK (2011) 38 pp. [ISBN 978058071382 8].

Pattara, C., Raggi, A., Cichelli, A., 2012. Life cycle assessment and carbon footprint in the wine supply-chain. Environ. Manage. 49, 1247-58.

Penela, A.C., García-Negro, M.D.C., Quesada, J.L.D., 2009. A methodological proposal for corporate carbon footprint and its application to a wine-producing company in Galicia, Spain. Sustainability 1, 302-318.

Point, E., Tyedmers, P., Naugler, C., 2012. Life cycle environmental impacts of wine production and consumption in Nova Scotia, Canada. J. Clean. Prod. 27, 11-20.

Point, E., 2008. Life cycle environmental impacts of wine production and consumption in Nova Scotia, Canada. Master's Thesis, Dalhousie University, Halifax, Nova Scotia.

Rugani, B., Vázquez-Rowe, I., Benedetto, G., Benetto, E., 2013. A comprehensive review of carbon footprint analysis as an extended environmental indicator in the wine sector. J. Clean. Prod. 54, 61-77.

Salvat, J., Boqué, J.B., 2009. New Opportunities and Challenges in Wine Tourism. http://www.pctturisme.cat/intranet/sites/default/files/URV_project_salvat_blay_seminar_pctto.pdf. 
Steen-Olsen, K., A. Owen, E.G. Hertwich and M. Lenzen, 2014. Effects of sectoral aggregation on CO2 multipliers in MRIO analyses. Economic Systems Research 26, 284-302.

Steenwerth K., Strong E.B., Greenhut R.F., Williams L., Kendall A., 2015. Life cycle greenhouse gas, energy, and water assessment of wine grape production in California. Int. J. Life Cycle Assess. 20, 1243-1253.

Suh, S. and G. Huppes, 2005. Methods for Life Cycle Inventory of a product. Journal of Cleaner Production 13, 687-697.

Suh, S., M. Lenzen, G.J. Treloar, H. Hondo, A. Horvath, G. Huppes, O. Jolliet, U. Klann, W. Krewitt, Y. Moriguchi, J. Munksgaard and G. Norris, 2004. System boundary selection in Life-Cycle Inventories. Environmental Science \& Technology 38, 657-664.

Suh, S. and S. Nakamura, 2007. Five years in the area of input-output and Hybrid LCA. International Journal of Life Cycle Assessment 12, 351-352.

Szolnoki, G., 2013. A cross-national comparison of sustainability in the wine industry. J. Clean. Prod. 53, 243251.

Thinkstep, 2015. GaBi6 software and professional databases (Ecoinvent 3.0; PE International, 2015; plastics Europe; ILCD).

Thomas, M., 2011. Life Cycle Assessment and the New Zealand Wine Industry: A tool to support continuous environmental improvement, Master Thesis, Massey University, Wellington, New Zealand.

Vázquez-Rowe, I., Villanueva-Rey, P., Iribarren, D., Teresa Moreira, M., Feijoo, G., 2012a. Joint life cycle assessment and data envelopment analysis of grape production for vinification in the Rías Baixas appellation (NW Spain). J. Clean. Prod. 27, 92-102.

Vázquez-Rowe, I., Villanueva-Rey, P., Moreira, M.T., Feijoo, G., 2012b. Environmental analysis of Ribeiro wine from a timeline perspective: harvest year matters when reporting environmental impacts. J. Environ. Manage. 98, 73-83.

Vázquez-Rowe, I., Rugani, B., Benetto, E., 2013. Tapping carbon footprint variations in the European wine sector. J. Clean. Prod. 43, 146-155.

Villanueva-Rey, P., Vázquez-Rowe, I., Moreira, M.T., Feijoo, G., 2014. Comparative life cycle assessment in the wine sector: Biodynamic vs. conventional viticulture activities in NW Spain. J. Clean. Prod. 65, 330-341.

Weidema, B.P., Thrane, M., Christensen, P., Schmidt, J., Løkke, S., 2008. Carbon footprint: A catalyst for life cycle assessment? J. Ind. Ecol. 12, 3-6.

WFA, Australian Wine Carbon Calculator. Winemakers' Federation of Australia. http://www.wfa.org.au/resources/carbon-calculator.

Wood, R., M. Lenzen, C. Dey and S. Lundie, 2006. A comparative study of some environmental impacts of conventionally and organically grown food. Agricultural Systems 89, 324-348. 